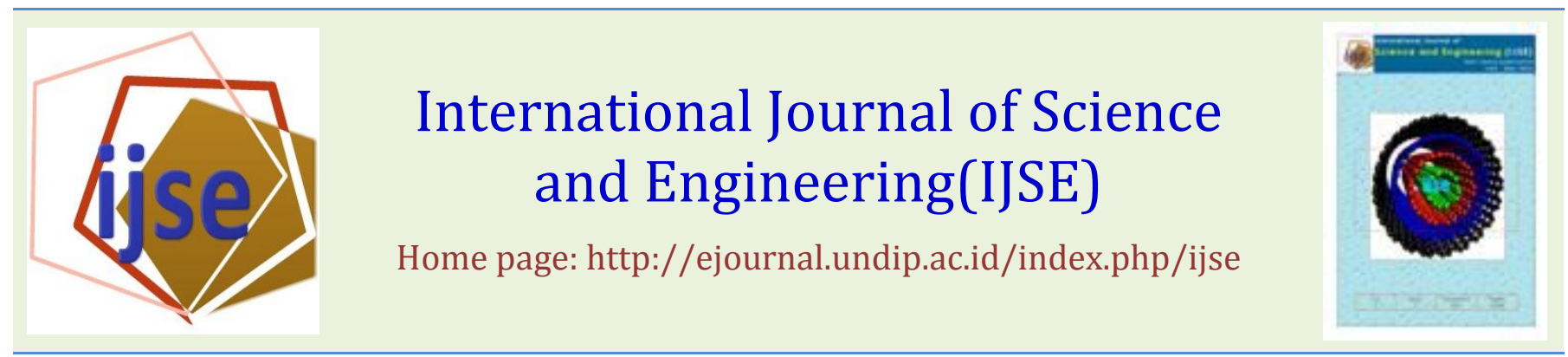

\title{
The Distribution of Capture Fisheries Based Small Pelagic- Mackerel Fish Species In Balikpapan Waters, East Kalimantan
}

\author{
Said Abdusysyahid ${ }^{1)}$, Sutrisno Anggoro2) and Azis Nur Bambang2) \\ 1)Fisheries and Marine Science Faculty of Mulawarman University, Kampus Gunung Kelua Samarinda, East Kalimantan \\ 75123
}

2)Fisheries and Marine Science Faculty of Diponegoro University, Jl. Prof. Soedarto, SH. Campus UNDIP Tembalang Semarang 50275

\section{Email: syahhids59@yahoo.co.id}

\begin{abstract}
In the utilization of common property resource, long term balance in aquaculture is difficult to maintain as people trying to maximize their profit leading to considerable extensification. The objective of this research was to analyze the number of stock, production, and effort of Mackerel fish (Scomberomorus commersonii) resource based on bioeconomic approach. Primary data was collected based on purposive sampling method where the respondents in this research were Small Pelagic fishers which determined deliberately due to specific consideration. Secondary data used in this research was obtained from several sources. Data production and effort (input or effort) was arranged in a time sequence according to the type of fishing gears and their targets of fishery resource being studied and then determined the value of CPUE (catch per unit effort). Mathematically, the input gear to be standardized is calculated from fishing power index multiplies with input (effort) of standardized gear. The result shows that the renewable capacity begins to decrease leading to a condition of biologically over fishing. Aside from that, the Mackerel fish resource in this area also experiences economically over fishing condition which indicated by higher economic calculation value and lower capture yield.
\end{abstract}

Keywords: potency; capture fishery; mackerel fish; bio-economy(;)

Submission: March 28, $2014 \quad$ Correction: April 1, 2014

Accepted: April 14, 2014

Doi: 10.12777 /ijse.6.2.149-153

[How to cite this article: Abdusysyahid, S., Anggoro, S. and Bambang, A.N. 2014. The Distribution of Capture Fisheries Based Small Pelagic- Mackerel Fish Species In Balikpapan Waters, East Kalimantan, International Journal of Science and Engineering, 6(2),149-153. Doi:10.12777/ijse.6.2.149-153]

\section{INTRODUCTION}

Fishing activity can be carried out either in coastal or off-shore area. In coastal area, small fishers use very simple technology to catch marine biota such as shellfish, mollusk, and plant vegetation including mangrove, algae, sea grass and so on. While fishing catchment in off-shore area, besides of small fishers, capital-intensive fishers play the most significant role (Jennings, and Kaiser, 1998).

In general, fishery resources are classified into four classes, namely Demersal fish resources, Small Pelagic resources, Large Pelagic resources and marine biota resources (Gulland, 1971). If exploitation exceeds the net annual production or disobey the existing rule then the destruction will be higher overtime which means that the resource begins to decrease (Koslow et al., 2000). In the utilization of common property resource, long term balance in aquaculture is difficult to maintain as people trying to maximize their profit which leads to considerable extensification (Allison et al., 1998).

National development should address fisheries sector as the main potential contribution due to their abundant resources. This abundance resource is one of the reasonable factors to industrialize fishery and marine sectors. An increasing number of fishers and other economic actors continually rise so that all the economic advantage will be distributed due to the open access characteristic where people is free to enter or leave the exploration project (Holland and Brazee, 1996). This causes exploitation of fisheries resource on a large scale that could damage the sustainability of this resource (Hastings and Botsford, 2003).

Balikpapan as one of the major city in East Kalimantan province has very strategic location for fishery development activities (Susanto and. Gordon. 2005). 
Statistic Office of Balikpapan (2009) noted that there are many exporter companies which have operated for more than 10 years. Some of fishery resource exploitation activities are fish capture, fish farming and processing of fish product (Heino, 1998).

In 2007, marine fisheries production of Balikpapan was still the primary contributor which accounted by $88.93 \%$ of the total fishery sub-sector or $5.990,16$ tons with production value reached up to IDR 38.348.860. This number was lower compared to the previous year i.e. 12.970 tons, 13.118 tons, 13.635 tons and 12.986 tons in 2006, 2005, 2004 and 2003, respectively. Mackerel fish (Scomberomorus commersonii) is one of the main commodities due to the economic value and high selling price. In 2006, the production reached up to 244.2 tons. However, the production dramatically decreased up to 8.8 tons in 2007. Thus, a study which concern on the investigation of dramatic decreasing production value of Mackerel fish in Balikpapan waters should be conducted (Fishery and Marine Office of Balikpapan, 2007).

Policies on fisheries issue such as overfishing, overcapacity, poverty, coastal environment, decentralization, fiscal, illegal fishing and others relevant policies are new scientific breakthrough in the perspective of management and utilization on maximizing the fishery and marine resource utilization.

\section{RESEARCH METHOD}

Primary data was collected based on purposive sampling method. In other words, respondent i.e. Small Pelagic fishers are determined deliberately due to specific consideration. Singarimbun and Effendi (1989) stated that purposive sampling is sampling method based on certain purposes. In this method, respondent is determined by data collector in accordance with the objective and purpose of the research. In this research, a respondent criterion is fishers who use gears to catch Small and Large Pelagic fish, Demersal, crustacean and mollusk. Sample of respondents were deliberately chosen due to these underlying factors:

1) Respondents were fishers who land their captures in fish auction center Manggar, Balikpapan,

2) Respondents were assumed could represent fishers who use gears for their operation,

3) Respondents were able to communicate well in filling the questionnaire,

4) Total respondents taken from whole population were 50 people, consisting of:

1. Fishers with trawl bag as many as 10 people,

2. Fishers with fishing gear as many as 30 people,

3. Fishers with gill nets as many as 10 people.

Data was collected through direct interview with Mackerel fishers based on the questioners (direct quantification).

Secondary data used in this research was obtained from several sources, such as:

1) Annual statistic report published by Fishery and Marine Office of Balikpapan for 10 years period;

2) Annual statistic report published by Fishery and Marine Office of East Kalimantan Province for 10 years period;

3) Statistic report published by Office of Statistic of
Balikpapan from 2010 to 2011 ;

4) Statistic report published by Office of Statistic of East Kalimantan Province from 2010 to 2011;

5) Research report published by Regional Development Office (BAPEDA) of Balikpapan and Regional Development Office of East Kalimantan.

Data production and effort (input or effort) was arranged in a time sequence according to the type of fishing gear and their targets of fishery resource being studied and then determined the value of CPUE (catch per unit effort). CPUE calculation was intended to determine the level of abundance and utilization of fishery resource in particular waters area. CPUE was written as follow (Gulland, 1983):

$$
C P U E_{t}=\frac{\text { catch }_{t}}{\text { effort }_{t}}
$$

Whereas:

$C P U E=$ catch per unit effort at year $-t$

Catch $_{t}=$ capture yield at year $-t$

effort $t_{t}=$ effort at year $-t$
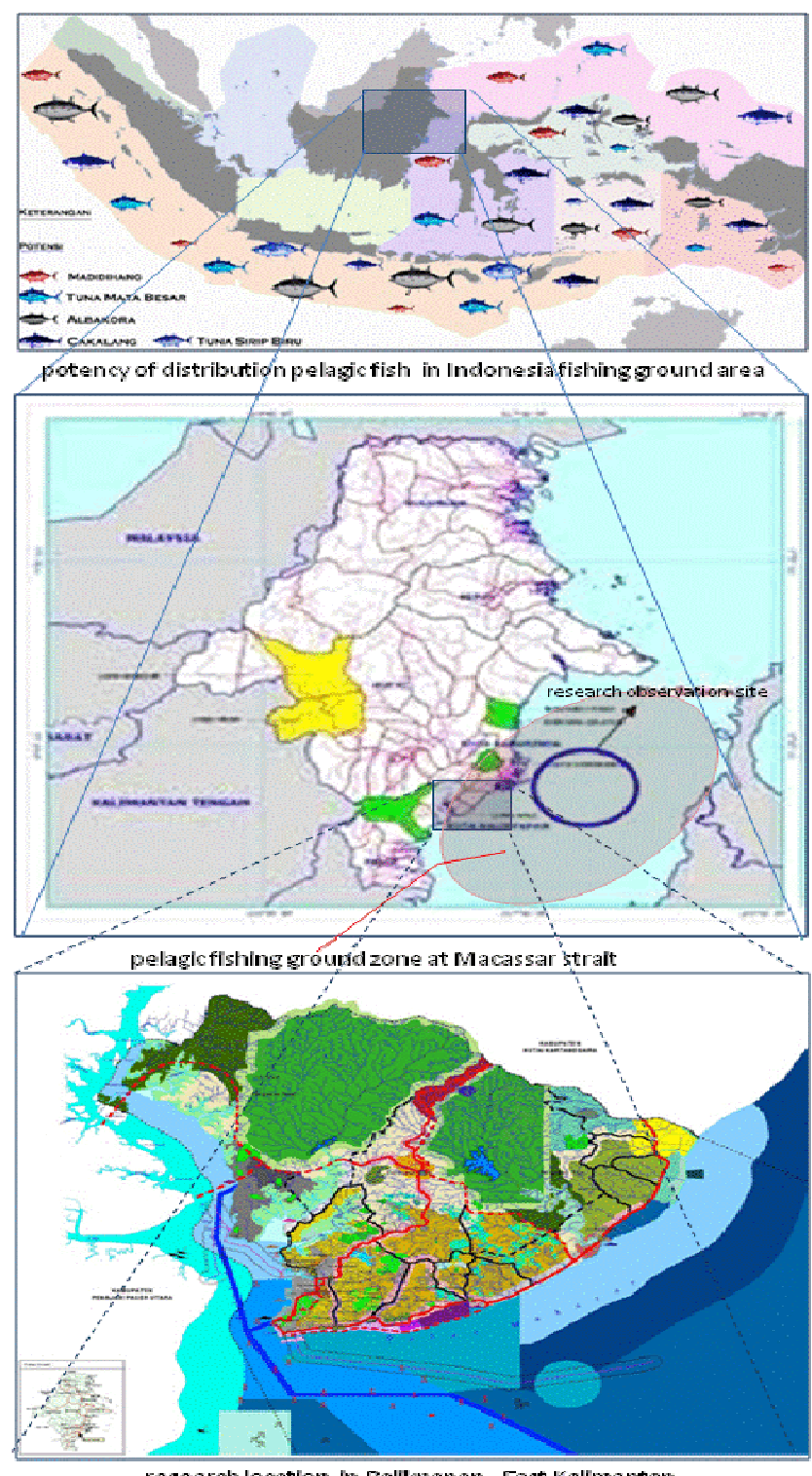

research location in Balikpapan, East Kallmantan

Figure 1. Research location map in Balikpapan, East Kalimantan 
According to Gulland (1983), the standardized gears is high productivity or dominant gear in capturing fishery resource being studied or having highest average CPUE at a period of time and having fishing power index equals to one. Mathematically, the input gear to be standardized is calculated from fishing power index multiplies with input (effort) of standardized gear (Fauzi, 2004).

$$
\begin{aligned}
& E_{s t d}=\varphi_{i} E_{i} \\
\varphi_{i}= & \frac{U_{i}}{U_{s t d}}
\end{aligned}
$$

whereas:

$$
\begin{array}{ll}
E_{s t d} & =\text { standard effort } \\
U_{i} & =\text { CPUE }=\text { Cacth per Unit Effort at catch- } i \\
U_{\text {std }} & =\text { CPUE }_{\text {std }}=\text { standardized CPUE }
\end{array}
$$

\section{III.RESULT AND DISCUSSION}

Balikpapan city consists of five sub-districts and 27 villages. Among those, there are four sub-districts and 16

\begin{tabular}{|c|c|c|c|}
\hline \multirow{3}{*}{ Sub-district/Village } & \multicolumn{3}{|c|}{ Potency of Fishery and Marine Resource } \\
\hline & \multirow{2}{*}{ Capture Fisheries } & \multicolumn{2}{|c|}{ Aquaculture Fisheries } \\
\hline & & Pond & Pool \\
\hline \multicolumn{4}{|l|}{ East Balikpapan } \\
\hline - Vil. Teritip & $\sqrt{ }$ & $\sqrt{ }$ & $\sqrt{ }$ \\
\hline - Vil. Lamaru & $\sqrt{ }$ & $\sqrt{ }$ & $\sqrt{ }$ \\
\hline - Vil. Manggar Baru & $\sqrt{ }$ & - & $\sqrt{ }$ \\
\hline - Kel. Manggar & $\sqrt{ }$ & $\sqrt{ }$ & $\sqrt{ }$ \\
\hline \multicolumn{4}{|l|}{ South } \\
\hline - Vil. Sepinggan & $\sqrt{r}$ & - & $\sqrt{r}$ \\
\hline - Vil. Gn. Bahagia & $\begin{array}{l}\sqrt{ } \\
\sqrt{ }\end{array}$ & - & $\sqrt{ }$ \\
\hline & & & \\
\hline - Vil. Klandasan Ilir & $\sqrt{ }$ & - & - \\
\hline - Vil. Klandasan Ulu & $\sqrt{ }$ & - & - \\
\hline \multicolumn{4}{|l|}{ West Balikpapan } \\
\hline - Vil. Margasari & $\sqrt{ }$ & - & - \\
\hline - Vil. Baru Tengah & $\sqrt{ }$ & - & - \\
\hline - Vil. Baru Ulu & $\sqrt{ }$ & - & - \\
\hline - Vil. Kariangau & $\sqrt{ }$ & $\sqrt{ }$ & $\sqrt{ }$ \\
\hline - Vil. Margomulyo & $\sqrt{ }$ & - & $\sqrt{ }$ \\
\hline $\begin{array}{l}\text { North Baliknanan } \\
\text { - Vil. Batu Ampar }\end{array}$ & - & $\sqrt{ }$ & $\sqrt{ }$ \\
\hline - Vil. Karang Joang & - & - & $\sqrt{ }$ \\
\hline
\end{tabular}
(sixteen) villages which have activity in fishery and marine sector:

Table.1. Potency of Fishery Resource found in Villages of Balikpapan

There are 14 villages which potential for the development of capture fisheries while two others villages are intended for aquaculture farming. Fishers distribution across 14 villages was based on their living place, while their fishing activity was carried out in Balikpapan waters area.

The area of Balikpapan is $503.30 \mathrm{~km}^{2}$ with the coastal area crossing over $45.6 \mathrm{~km}$ length from Kariangau village to Teritip village, making it categorized as famous and potential coastal city.
The potential utilized area for marine or coastal resources is 4 miles from the coastline which governed in Act No. 32 year 2004 concerning on Regional Development. Thus, the potency of capture fisheries from a total area of Balikpapan $503.30 \mathrm{~km}^{2}$ is $337.805 \mathrm{~km}^{2}$ crossing over Makassar straits and Balikpapan bay with coastline of $45.6 \mathrm{~km}$ length and the marine fisheries resource potency is 16.850 tons/year. Aside from that, high fishery ground located of more than 12 miles and ZEE which is the central authority still remains free from the access of the small fishers.

According to the report of Fishery and Marine Office of Balikpapan (2010), Mackerel fish resource found in

\begin{tabular}{|c|c|c|}
\hline No. & Local name & Latin name \\
\hline 1 & Baronang & Siganus sp \\
\hline 2 & Belanak & Valamugil seheli \\
\hline 3 & Bilis tembaga & Anchoviclla commersoni \\
\hline 4 & Ikan kakatua & Chlorurus sordidus \\
\hline 5 & Ikan kue & Caranx Sexfasciatus \\
\hline 6 & Ikan sarden & Clupeidae \\
\hline 7 & Ikan tembang & Sardinella gibbosa \\
\hline 8 & Kakap anjing & Latjanus jocu \\
\hline 9 & Kakap batu & Latjanus griseus \\
\hline 10 & Kakap domba & Latianus analis \\
\hline 11 & Kakap merah & Lutjanus capprchanus \\
\hline 12 & Kakap ratu & Latjanus oculatus \\
\hline 13 & Kakap sirip hitam & Latjanus buccanella \\
\hline 14 & Kakap sutra & Latjanus vivanus \\
\hline 15 & Kembung laki-laki & Rastrelliger kanagurta \\
\hline 16 & Kembung perempuan & Rastrelliger negletus \\
\hline 17 & Kerapu & Epinephelus fuscoguttatus \\
\hline 18 & Kerapu bebek & Cromileptes altivalis \\
\hline 19 & Kerapu biru & Epinophilus flavoucoenules \\
\hline 20 & Kerapu lumpur & Epinephelus Coiodes \\
\hline 21 & Kerapu sunu & Plectrocopomus leopardus \\
\hline 22 & Kurisi & Nemipterus nemotophorus \\
\hline 23 & Kuwe Batu Besar & Seriola Dumerili \\
\hline 24 & Kuwe Florida & Trachinotus Carolinus \\
\hline 25 & Kuwe Gerong & Caranx Ignobilis \\
\hline 26 & Kuwe gerong & Caranx Ignobilis \\
\hline 27 & Kuwe Lilin & Caranx Hippos \\
\hline 28 & Kuwe Rambe & Alectis Ciliaris \\
\hline 29 & Layang & Detapterus pusailus \\
\hline 30 & Layaran & Istiophorus oriantalis \\
\hline 31 & Pari Burung Elang & Aetomyleus nichofii \\
\hline 32 & Pari Keprak & Aetoplatea Zonura \\
\hline 33 & Pari Macan & Himantura Undulata \\
\hline 34 & Permit & Trachinotus Falcatus \\
\hline 35 & Sunglir & Elagatis Bipinnulata \\
\hline 36 & Tenggiri & Scomberomorus guttatus \\
\hline 37 & Tenggiri & Scomberomorus \\
\hline 38 & Tengkek & Caranx Crysos \\
\hline
\end{tabular}
Balikpapan waters consisted of different kinds of fishes, i.e.:

Table 2. Latin and local name of fishes found in Balikpapan waters (2014)

There are two kinds of Mackerel fish found in Balikpapan, namely:

1. Tenggiri, Scomberomorus commerson (Lacepede), Narrow-barred King Mackerel. 


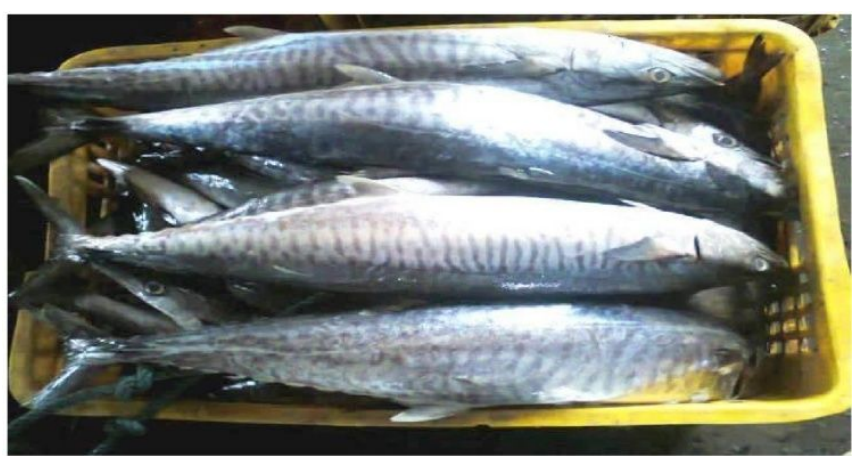

The first dorsal fin is 15-18 spines, usually 17 , second dorsal is 15-20 spines, usually 17 or 18 ; followed by small dorsal fin 8-11, usually 9 or 10; anal fin is 7-12, usually 9 or 10; pectoral fin rays is $21-24$, usually 22 or 23 ; vertebrae is $42-46$, usually 44 or 45 . Gillrakers on first arch few is $(0-2)+(1-8)$, usually $(0-1)+(3-4)=3-5$. The maximum size is $230 \mathrm{~cm}$ FL and $59 \mathrm{~kg}$, usually $60-120$ $\mathrm{cm}$. Female species has larger size than the male size. The color of both sides is silvery grey marked with transverse vertical bars of a darker grey, slightly wavy, sometimes breaking up into spots ventrally.

Similar to the other species from Scomberomorus family, $S$. commerson eats smaller fishes particularly teri fishes, Stolephorus, Anchoviella and also kupleid species such as Sardinella. Other feeding sources are small karanggid species, peperek (Leiognathidae), squid (Loligo), and some species of peneid shrimp. They could eat all day long (Tongyai, 1970). This species belongs to pelagic fish, found in the small groups of fishes in coastal area at $15 \mathrm{~m}$ to $200 \mathrm{~m}$ depth (Fischer and Whitehead, 1974).

2. Tenggiri papan, Scomberomorus guttatus (Bloch and Schneider), Indo-Pacific King Mackerel.

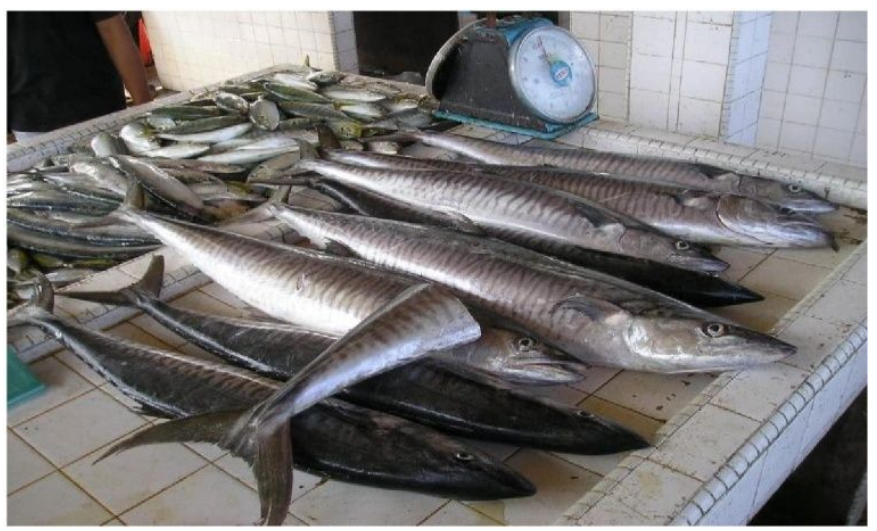

Lateral line is gradually curving down toward caudal peduncle. The first dorsal fin is 15-18 spines, usually 16 or 17 ; the second dorsal fin is 18 to 24 spines, usually $20-22$; small dorsal fines is 7-10, usually 8-9; anal fin is 19-23 rays, usually $20-22$ rays and $7-10$ spines, usually 8 spines; pectoral fin is $20-23$ rays, usually 21 . Total vertebrae are 47-52, usually 50 or 51 . Gill rakers on the first arch is (1-2) $+(7-12)=8-14$, usually $2+(9-10)=11-12$.

The maximum size is $76 \mathrm{~cm}$ FL. The color is greyish blue at the dorsal side and silvery white at the lateral and ventral side. Longitudinal rows of dark brownish spot is scattered and centered along lateral line. First dorsal fin membrane is black. The color of caudal fins, pectoral, second dorsal and pelvic is blackish brown. While the ventral and anal fins are silvery white.

Similar to other Scomberomorus, the main food of $S$. guttatus is fish. During juvenile period, this species feeds telestei variety particularly klupeid. While mature fish feeds small number of crustacean and squid besides of klupeid. Teri including Stolephorus and Anchoviella is also the main food for this species.

This species belongs to pelagic fish, lives in coastal area at $15 \mathrm{~m}$ to $200 \mathrm{~m}$ depth and found in small groups of fishes (Fischer and Whitehead 1974).

Mackerel is regarded as important fish due to the economic value and popular worldwide. This fish is geographically distributed crossing over West Pacific from North Africa to Red Sea and Indonesia, Australia and Fiji waters and spread over to the north reaching up to China and Japan waters. In Indonesia, Mackerel fish is distributed over Sumatra, Jawa, Nusa Tenggara, Kalimantan, Sulawesi, Maluku and Irian waters. Tropical climate such as in Indonesia is the most favorable climate condition for Mackerel fish. Besides of Indonesia, mackerel fish is also found in the north side of China and Japan, south east side of Australia and even in Red Sea. Suitable depth for Mackerel fish is approximately 10-70 m below sea surface.

Data on the number of input aggregate (total effort) of fishery resource is required in order to analyze the bioeconomic value for optimizing the fish resource itself (Sissenwine and Shepherd, 1987). The characteristic of fishery resource found in Indonesia is generally multi species with multi gears. Thus, the capability of each gears, species and number of species is different. Standardization of fishing gear towards standardized gear with high productivity is used to determine the capture capability of fishers.

In studying Mackerel fish resource, standardization of fishing gear was conducted based on the highest productivity of fishing gear. Mackerel fishes were caught by trawl, gill nets and fishing rods. The fishing gears i.e. trawl and gill net were standardized toward the fishing rods. Figure below shows comparison of each CPUE, production and effort of Mackerel fish in Balikpapan.

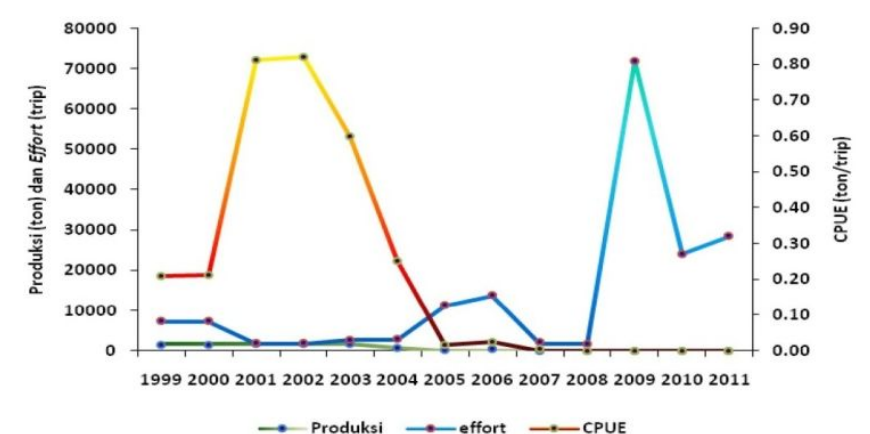

Figure 4. Comparison of production, effort and CPUE in the mackerel fishery in 1999-2011

Illustrates the comparison of production, effort and CPUE in the mackerel fishery during 1999-2011. From the figure above, it can be seen that production number tends to decrease. The production in 1999 reached up to 1.539 tons per year and sharply decreased up to 1.42 tons per 
year in 2011. Meanwhile, the effort fluctuates over the years. The highest effort was found in 2009 with 72.125 trips per year. Fluctuation also emerges in CPUE number following the trend occurred in production and effort. The highest CPUE number occurred in 2002 with 0.8212 tons per trip per year while the lowest occurred in 2011 with 0.00005 tons per trip per year (Figure 4).

The sharp difference between production fluctuation and effort indicated from 1999 to 2011 was due to several factors, including: high increasing number on the mackerel production during 1999 to 2002 thus depletion of mackerel fish stock had occurred from 2003 until 2005. The following years i.e. 2006 to 2011, the production of mackerel fish was low due to over fishing.

Sustainable production is a condition where capture effort and its capture volume will not endanger the sustainability of fishery resource. It is demonstrated by quadratic curve which correlates capture volume (production) with capture effort. The estimation of sustainable production is obtained by substituting the biological parameter value into the equation. The result of this calculation is regarded as sustainable production function or sustainable yield-effort curve.

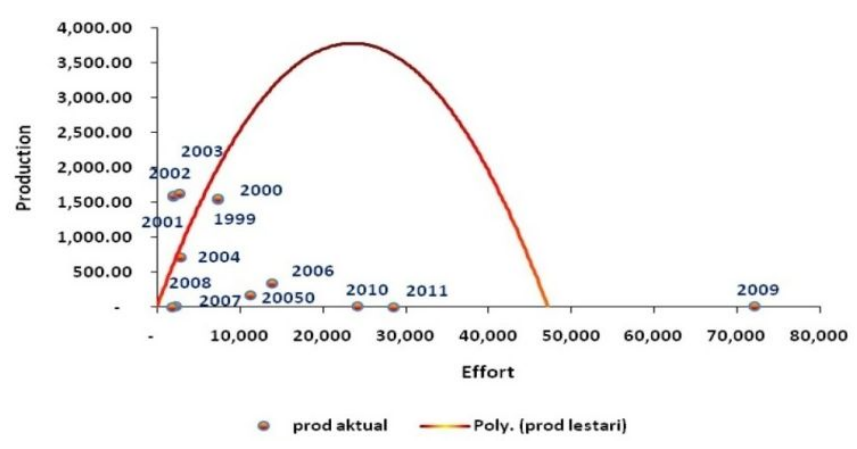

Figure 6. Curve of Sustainable Production, Actual Production and Effort of Tenggiri Fish Resource

Illustrates that during 1999-2011 most of actual production volume of mackerel fish resource placed inside the sustainable curve (Fig 6). However, the actual production volume placed outside the sustainable curve in the 2001 to 2003 and 2009. This condition demonstrates that the renewable capacity of Mackerel fish resource has decreased leading to a condition of biologically overfishing.

\section{CONCLUSION}

Mackerel fish resource in Balikpapan waters had not shown degradation and depreciation during 1999-2011. However, the renewable capacity begins to decrease leading to a condition of biologically over fishing. Aside from that, the Mackerel fish resource in this area experiences economically over fishing condition which indicated by higher economic calculation value and lower capture yield. According to this situation, the recommendation on resource management strategy relies on the divestment policy i.e. reducing the uses of fishing gears which indicates over capacity in the utilization of fishery resource including mackerel fish.
Massive conversion of mangrove forest particularly Nypa (Nypa fruticans) area into pond has driven conflict among related stakeholders on the utilization of natural resource and the area. It impacts on the fish and shrimp source regeneration, loss of ecological functions of mangrove forest for feeding, nursery and spawning ground of fish and other organisms.

Besides of fisheries, oil and gas activity also exists in Mahakam Delta. Mahakam Delta is regarded as important area due to the largest producer of oil and gas mining. Thus, oil and gas industry is the most reliable sector that contributes to the economic development of Kutai Kartanegara. As a resource provider, Mahakam Delta ecosystem provides various resources for livelihoods. As a life-support service provider, Mahakam Delta ecosystem provides habitat and ideal environment to support variety of living kinds. As a convenience provider, Mahakam Delta ecosystem provides unique and interesting recreation site. As a protector from natural disaster, Mahakam Delta ecosystem is able to protect humankinds from natural disaster threatening coastal area.

\section{REFERENCES}

[1] Allison, G. W., J. Lubchenco, and M. H. Carr. 1998. Marine reserves are necessary but not sufficient for marine conservation. Ecological Applications 8:79-92.

[2] Fauzi, A. 2004. Ekonomi Sumberdaya Alam dan Lingkungan: Teori dan Aplikasi.: PT Gramedia Pustaka Utama. Jakarta. 259 p. (in bahasa).

[3] Fischer, W and P. J.P. Whitehead (eds), 1974. FAO Spesies Identification Sheet for Fishery Purpose, Eastern Indian Ocean (Fishing Area 57) and Western Central Pasific (Fishing Area 71) Rome, FAO, Volume 1. (Unpaged).

[5] Fishery and Marine Departement. 2007. Fishery and marine statistic report of Balikpapan 2006. Fishery and Marine Office of Balikpapan.

[6] Fishery and Marine Departement. 2010. Fishery and marine statistic report of Balikpapan 2009. Fishery and Marine Office of Balikpapan.

[7] Gulland, J. A. 1971. The Fish Resources of the Ocean. Fishing News Books, West Byfleet, England. 255 pp.

[8] Gulland. J.A. 1983. Fish Stock Assesment : Manual of Basic Method. New York : Wiley and Sons Inter-science. Volume 1, FAO/Wiley Series on Food and Agricultural. 233 p.

[9] Hastings A and L. W. Botsford. 2003. Comparing Designs of Marine Reserves for Fisheries and for Biodiversity. Ecological Applications, 13 (1) Supplement, S65-S70.

[10] Heino, M. 1998. Management of evolving fish stocks. Canadian Journal of Fisheries and Aquatic Sciences, 55: 1971-1982.

[11] Holland, D. S., and R. J. Brazee. 1996. Marine reserves for fishery management. Marine Resource Economics 11:157- 171.

[12] Jennings, S., and Kaiser, M. J. 1998. The effects of fishing on marine ecosystems. Advances in Marine Biology, 34: 201-352.

[13] Koslow J. A., G. W. Boehlert, J. D. M. Gordon, R. L. Haedrich, P. Lorance, and N. Parin. 2000. Continental slope and deep-sea fisheries: implications for a fragile ecosystem. ICES Journal of Marine Science, 57: 548-557. doi:10.1006/jmsc.2000.0722.

[14] Singarimbun, M. dan S. Effendi. 2002. Metode Penelitian Survey. (LP3ES) Lembaga Penyelidikan, Penelitian, Pengembangan Ekonomi dan Sosial. Jakarta. 336 p (in bahasa).

[15] Sissenwine, M. P., and J. G. Shepherd. 1987. An alternative perspective on recruitment overfishing and biological reference points. Canadian Journal of Fisheries and Aquatic Science 44:91391.

[16] Susanto, R.D. and A. L. Gordon. 2005. Velocity and transport of the Makassar Strait Through flow. Journal of Geophysical Research 110, Jan C01005, doi:10.1029/2004JC002425 